\title{
Structural, thermal, in vitro degradation and cytocompatibility properties of $\mathrm{P}_{2} \mathrm{O}_{5}-\mathrm{B}_{2} \mathrm{O}_{3}-\mathrm{CaO}-\mathrm{MgO}-\mathrm{Na}_{2} \mathrm{O}-\mathrm{Fe}_{2} \mathrm{O}_{3}$ glasses
}

\author{
Chenkai Zhu abc, Ifty Ahmed ${ }^{a}$, Andy Parsons ${ }^{a}$, Kazi Zakir Hossain ${ }^{a}$, Chris Rudd ${ }^{a b c}$, \\ Jingsong Liu ${ }^{d}$, Xiaoling Liu ${ }^{b c *}$ \\ a. Division of Materials, Mechanics and Structures, Faculty of Engineering, University of \\ Nottingham, Nottingham, U.K \\ b. Ningbo Nottingham New Materials Institute, University of Nottingham Ningbo China, Ningbo, \\ 315100, China \\ c. Ningbo Nottingham International Academy for the Marine Economy and Technology, \\ University of Nottingham Ningbo China, Ningbo, 315100, China \\ d. Department of Technology, Sinoma Co., Ltd.,198 Tongtian Road, Nanjing, 211100, China
}

\section{ABSTRACT}

Borophosphate glasses with compositions of $(48-\mathrm{x}) \mathrm{P}_{2} \mathrm{O}_{5}-(12+\mathrm{x}) \mathrm{B}_{2} \mathrm{O}_{3}-14 \mathrm{CaO}-20 \mathrm{MgO}-1 \mathrm{Na}_{2} \mathrm{O}-5 \mathrm{Fe}_{2} \mathrm{O}_{3}$ (where $\mathrm{x}=0,3,8 \mathrm{~mol} \%$ ) were prepared via a melt-quenching process. The effects of replacing $\mathrm{P}_{2} \mathrm{O}_{5}$ with $\mathrm{B}_{2} \mathrm{O}_{3}$ on the structural, thermal, degradation properties and cytocompatibility were investigated. Fourier Transform Infrared (FTIR) spectroscopy analysis confirmed the existence of $\mathrm{BO}_{3}$ triangular units and $\mathrm{BO}_{4}$ tetrahedral units within all the glasses with an increase of $\mathrm{B} / \mathrm{P}$ ratio from 0.25 to 0.5 . The $\mathrm{BO}_{4}$ units within the glass structure were observed to cause an increase in density $(\rho)$ as well as glass transition $\left(T_{g}\right)$ temperature and to decrease the crystallisation temperature $\left(T_{c}\right)$. A decrease in thermal stability which indicated by process window was also observed in the case of substitution of $\mathrm{P}_{2} \mathrm{O}_{5}$ with $\mathrm{B}_{2} \mathrm{O}_{3}$. Degradation analysis of the glasses indicated that the dissolution rate increased with the addition of $\mathrm{B}_{2} \mathrm{O}_{3}$. The decrease in the thermal stability and chemical durability were attributed to the increase of $\mathrm{BO}_{3}$ units, which could increase crystallisation tendency and be easily hydrolysed by solution. The effect of boron addition on the cytocompatibility of the glasses was analysed using Alamar Blue and Alkaline Phosphatase (ALP) assays and DNA quantification. MG63 osteosarcoma cells cultured in direct contact with the glass samples surface for 14 days showed better cytocompatibility, compared to the Tissue Culture Plastic (TCP) control group. In summary, the glass formulation with $12 \mathrm{~mol} \% \mathrm{~B}_{2} \mathrm{O}_{3}$ presented the best cytocompatibility and thermal stability, thus could be considered for continuous fibre fabrication in future research and downstream activities.

Keywords: Borophosphate glass, thermal properties, glass structure, degradation, cytocompatibilty 


\section{INTRODUCTION}

Bioresorbable and bioactive materials with excellent biocompatibility and sufficient mechanical properties have been the subject of much interest in recent studies [1-5]. In the early 1970s, Hench and his colleagues developed the first bioactive glass, which elicited a specific biological response at the material surface resulting in the formation of a bond between the bioactive glass and bone $[6,7]$. Bioglass ${ }^{\circledR}$ 45S5 which consists of $45 \mathrm{wt} \% \mathrm{SiO} 2,6 \mathrm{wt} \% \mathrm{P} 2 \mathrm{O}$, $24.5 \mathrm{wt} \% \mathrm{CaO}$ and $24.5 \mathrm{wt} \% \mathrm{Na} 2 \mathrm{O}$, became a benchmark for novel silicate-based bioactive glasses, having shown success for application in dentistry and orthopaedics $[8,9]$. However, lack of control over the glass degradation rate can limit its application and has stimulated research for new bioactive and bioresorbable glasses as potential alternatives [10]. In the last two decades, an alternative bioresorbable material, totally free of silica referred to as phosphate based glasses have been considered as potential materials for the repair and reconstruction of bone [11-13]. Their degradation rate can easily be varied from hours to several weeks to many months just by changing their composition [14-16].

Phosphate based glasses (PBGs) are composed of (PO4) $)^{3-}$ tetrahedral units that form the backbone of the glass $[17,18]$. The tetrahedral units are classified using the $\mathrm{Q}^{\mathrm{i}}$ terminology, where i represent the number of bridging oxygens (BO) per tetrahedral unit and range from 0-3 [19, 20]. Many phosphatebased glass formulations have been reported as being biocompatible and subtle alterations to their composition has shown a wide variation of mechanical and thermal properties [21-23]. Ahmed et al. investigated phosphate based glass in the system $40 \mathrm{P}_{2} \mathrm{O}_{5}-25 \mathrm{CaO}-20 \mathrm{MgO}-15 \mathrm{Na}_{2} \mathrm{O}$ which showed good cellular response [24] and Hasan et al. studied the system $45 \mathrm{P}_{2} \mathrm{O}_{5}-16 \mathrm{CaO}-24 \mathrm{MgO}-11 \mathrm{Na} 2 \mathrm{O}-4 \mathrm{Fe}_{2} \mathrm{O}_{3}$, which also showed good cytocompatibility and proved successful for fibre drawing [25].

Several studies have shown that mixed glass network formers, such as doping phosphate based glass systems with $\mathrm{B}_{2} \mathrm{O}_{3}$, can improve glass thermal stability and chemical durability due to the creation of cross-linked phosphate chains with B-O-P bridges and the formation of $\mathrm{BO}_{4}$ units, which suppressed their tendency to crystallise and increased network cross-linking density [26-31]. By using boron, a 
common issue associated with phosphate glass fibre drawing, i.e. the tendency for crystallisation at working process temperature was reduced $[32,33]$. Larink et al. investigated the effect of $\mathrm{B}_{2} \mathrm{O}_{3}$ addition into phosphate glass and stated that $\mathrm{T}_{\mathrm{g}}$ and density of the borophosphate glasses increased until the $\mathrm{B} / \mathrm{P}$ ratio reached one [34]. Similar results were also presented by Lim et al., who investigated eight glass compositions in the system $\mathrm{P}_{2} \mathrm{O}_{5}-\mathrm{B}_{2} \mathrm{O}_{3}-\mathrm{SnO}$ and reported that this improvement was ascribed to the formation of covalent B-O-P bonding producing a stronger, better chemically resistant glass network [35].

Cytocompatibility analysis of bioactive borate glasses system $\mathrm{B}_{2} \mathrm{O}_{3}-\mathrm{SiO}_{2}-\mathrm{P}_{2} \mathrm{O}_{5}-\mathrm{CaO}-\mathrm{Na}_{2} \mathrm{O}$ revealed that the addition of $\mathrm{B}_{2} \mathrm{O}_{3}$ was shown to increase the rate of conversion to a hydroxyapatite layer on the surface of glasses remarkably [36-38]. Furthermore, the presence of boron supported the growth and proliferation of human stem cells and showed stimulation of RNA synthesis in fibroblast cells [39, 40]. However, if the concentration of borate ions $\left(\mathrm{BO}_{3}{ }^{3-}\right)$ leaching out of the glass rose above a certain threshold value this was shown to inhibit proliferation of the cells [38]. Fu et al. reported that dissolution products of bioactive borosilicate glasses supported the proliferation and function of bone marrow stromal cells for boron concentrations below a value of $0.65 \mathrm{mM}$ [36]. Sharmin et al. also showed that the bulk glass system $\mathrm{P}_{2} \mathrm{O}_{5}-\mathrm{CaO}-\mathrm{MgO}-\mathrm{Na}_{2} \mathrm{O}$ with $\mathrm{B}_{2} \mathrm{O}_{3}$ additions below $10 \mathrm{~mol} \%$ possessed good thermal stability and notable positive cellular response to MG63 cells in terms of cell viability and proliferation [32].

With regards to the results shown in the studies above, the thermal stability of the phosphate glass system, an essential property associated with fibre drawing, could be improved by doping with $\mathrm{B}_{2} \mathrm{O}_{3}$. However, high boron content in the glass system could lead to too much boron leaching into the surrounding media and inhibiting cell proliferation. For bioactive borophosphate glass systems, there does not appear to be any agreement regarding a glass formulation with suitable bioactivity for bone repair applications and especially industrial scale fibre manufacturing properties. In order to define glass formulations with a combination of excellent biocompatibility, suitable degradation rate and good 
fibre drawing properties, the chemical composition of the glasses could be tailored by doping with $\mathrm{Fe}_{2} \mathrm{O}_{3}$ and controlling the ratio of $\mathrm{P}_{2} \mathrm{O}_{5}$ and $\mathrm{B}_{2} \mathrm{O}_{3}$.

Therefore, the main aim of this study was to investigate the effect of $\mathrm{B} 2 \mathrm{O} 3$ addition on the thermal, degradation and cytocompatibility properties of a new range of phosphate based glasses. Based on the established phosphate glass system $\mathrm{P}_{2} \mathrm{O}_{5}-\mathrm{CaO}-\mathrm{MgO}-\mathrm{Na}_{2} \mathrm{O}[24,25,32]$, a range of novel complex PBGs in the system of $(48-\mathrm{X}) \mathrm{P}_{2} \mathrm{O}_{5}-(12+\mathrm{X}) \mathrm{B}_{2} \mathrm{O}_{3}-20 \mathrm{MgO}-14 \mathrm{CaO}-1 \mathrm{Na}_{2} \mathrm{O}-5 \mathrm{Fe}_{2} \mathrm{O}_{3}$ were considered and an investigation into their structural, thermal, degradation and in vitro cytocompatibility properties has been conducted. The effect of $\mathrm{B}_{2} \mathrm{O}_{3}$ addition on the glass density was also evaluated. Degradation studies of the glasses were conducted in phosphate buffer saline (PBS) solution and MG63 osteosarcoma cell line was used for the cytocompatibility analysis.

\section{MATERIALS AND METHODOLOGY}

\subsection{Glass preparation}

Three different glass compositions (as shown in Table 1 with respective glass codes) were prepared using sodium dihydrogen phosphate $\left(\mathrm{NaH}_{2} \mathrm{PO}_{4}\right)$, calcium hydrogen phosphate $\left(\mathrm{CaHPO}_{4}\right)$, magnesium hydrogen phosphate trihydrate $\left(\mathrm{MgHPO}_{4} \cdot 3 \mathrm{H}_{2} \mathrm{O}\right)$, boric acid $\left(\mathrm{H}_{3} \mathrm{BO}_{3}\right)$, and phosphorous pentoxide $\left(\mathrm{P}_{2} \mathrm{O}_{5}\right)$ (Sigma Aldrich, UK) as starting materials. Briefly, the precursors were mixed together and then transferred to a Pt/5\% Au crucible (Birmingham Metal Company, UK) before preheating in a furnace for half an hour at $350{ }^{\circ} \mathrm{C}$. The dried powders were then melted at $1200{ }^{\circ} \mathrm{C}$ for $1.5 \mathrm{~h}$, after which the resulting molten glasses were poured onto a steel plate and allowed to cool at room temperature. At this stage a portion of each glass was ground into powder (utilising a pestle and mortar) to determine the $T_{g}$ value via DSC analysis (see thermal analysis section). Once $T_{g}$ values were obtained, the glasses were re-melted at $1200{ }^{\circ} \mathrm{C}$ and then poured into a graphite mould to manufacture rods $(9 \mathrm{~mm}$ diameter and approximately $70 \mathrm{~mm}$ length) and conditioned at $450{ }^{\circ} \mathrm{C}$ for 2 hours before cooling down to room temperature at a rate of $0.3{ }^{\circ} \mathrm{C} \mathrm{min}^{-1}$. Once cooled, the resulting rods were annealed by heating to $\mathrm{T}_{\mathrm{g}}+$ $10{ }^{\circ} \mathrm{C}$ (see Table 3 ) at a rate of $1{ }^{\circ} \mathrm{C} \mathrm{min}-1$ and held for $1.5 \mathrm{~h}$ isothermally before being cooled down to 
room temperature at a rate of $0.3{ }^{\circ} \mathrm{C} \mathrm{min}-1$. Finally, all the glass rods were cut into discs (measuring 10 $\mathrm{mm}, 7 \mathrm{~mm}$ and $2 \mathrm{~mm}$ in thickness) using a low speed diamond wheel saw (model 650, South Bay Technology Inc.). Ethanol (99\% Fisher Chemicals, UK) was utilised as a lubricating agent.

Table 1: Glass compositions used in this study, (in mol\%)

\begin{tabular}{|c|c|c|c|c|c|c|c|c|}
\hline Glass Code & $\mathbf{P}_{2} \mathbf{O}_{5}$ & $\mathbf{B}_{2} \mathbf{O}_{3}$ & $\mathbf{C a O}$ & $\mathbf{M g O}$ & $\mathbf{N a}_{2} \mathbf{O}$ & $\mathbf{F e}_{2} \mathbf{O}_{3}$ & $\begin{array}{c}\text { B/P } \\
\text { ratio }\end{array}$ & $\begin{array}{c}\text { Annealing } \\
\text { (temp C/time } \\
\text { in hours) }\end{array}$ \\
\hline $\mathbf{P 4 8 B 1 2}$ & 48 & 12 & 14 & 20 & 1 & 5 & 0.25 & $550 / 1.5$ \\
\hline $\mathbf{P 4 5 B 1 5}$ & 45 & 15 & 14 & 20 & 1 & 5 & 0.33 & $558 / 1.5$ \\
\hline $\mathbf{P 4 0 B 2 0}$ & 40 & 20 & 14 & 20 & 1 & 5 & 0.5 & $576 / 1.5$ \\
\hline
\end{tabular}

\subsection{Powder X-Ray Diffraction Analysis (XRD)}

In order to confirm the amorphous state of all the glass compositions, powder X-ray diffraction spectra were obtained using a Bruker D500 X-ray diffractometer. The measurements were taken at room temperature and ambient atmosphere with $\mathrm{Ni}$-filtered $\mathrm{CuK} \alpha$ radiation $(\lambda=0.15418 \mathrm{~nm})$, operated at 40 $\mathrm{kV}$ and $40 \mathrm{~mA}$. The scans were performed with an angular range $2 \theta$ from $15^{\circ}$ to $100^{\circ}$, a step size of $0.02^{\circ}$ and a step time of $0.5 \mathrm{~s}$.

\subsection{Fourier Transform Infrared Spectroscopy (FTIR)}

Fourier transform infrared spectroscopy was performed on around 1-2 mg samples of glass powder, using a Bruker Tensor 27 spectrometer (Bruker Optics, Germany). Spectra were recorded in the region of 500 to 4000 wavenumbers using a standard MKII Golden GateTM Single Reflection Attenuated Total Reflectance (ATR) system (Specac Ltd.) and analysed using OPUS software version 5.5. 


\subsection{Thermal analysis}

Thermal properties of the glasses were determined using a DSC Q600 calorimeter (TA Instruments, USA). Samples of approximately $30 \mathrm{mg}$ of the glass powders were heated from room temperature to $650{ }^{\circ} \mathrm{C}$ at $20{ }^{\circ} \mathrm{C}$ min-1 under argon gas flow $(50 \mathrm{ml}$ min-1). A blank run was carried out to determine the baseline, which was then subtracted from the sample traces. The Tg was extrapolated from the midpoint in the endothermic reaction of the heat flow.

After obtaining the $T_{g}$ value of the various compositions (in triplicate), fresh samples were subjected to a programmed heating cycle. For the first programmed cycle, $30 \mathrm{mg}$ samples of the glass powders were heated from room temperature to $\mathrm{T}_{\mathrm{g}}+20{ }^{\circ} \mathrm{C}$ at a rate of $20{ }^{\circ} \mathrm{C} \mathrm{min}^{-1}$, held there isothermally for 15 minutes and then cooled down at a rate of $10{ }^{\circ} \mathrm{C} \mathrm{min}^{-1}$ to $40{ }^{\circ} \mathrm{C}$ before ramping up again to $1200{ }^{\circ} \mathrm{C}$ at a rate of $20{ }^{\circ} \mathrm{C}$ min-1 under flowing argon gas. The first deviation of the DSC curve from the base line above $\mathrm{T}_{\mathrm{g}}$ and before the crystallisation peak was taken as the onset of crystallisation temperature $\mathrm{T}_{\text {onc }}$. The thermal stability of the glass was indicated in terms of the processing window $\mathrm{T}_{\mathrm{pw}}$ by measuring the interval between $\mathrm{T}_{\mathrm{g}}$ and $\mathrm{T}_{\text {onc }}[33,41]$ :

$\mathrm{T}_{\mathrm{pw}}=\mathrm{T}_{\mathrm{onc}}-\mathrm{T}_{\mathrm{g}}$ Equation 1

\subsection{Density measurement}

The density of the glasses was determined using a MicrometeriticAccuPyc 1330 helium pycnometer (Norscross, GA, USA). The equipment provides an accurate measurement of volume and is calibrated by using a standard steel calibration ball $(2.18551 \mathrm{~cm} 3)$, with errors of $\pm 0.05 \%$. Triplicate, bubble-free bulk glass samples with an average weight of approximately $6.5 \mathrm{~g}$ were used for the volume measurements. For each composition the molar volume (Vm) was also calculated using the following equation:

$\mathrm{V}_{\mathrm{m}}=\frac{\sum\left(\mathrm{x}_{\mathrm{i}} \cdot \mathrm{M}_{\mathrm{i}}\right)}{\rho}$ Equation 2 
Where $\rho$ is the density, $x_{i}$ is the molar fraction of component $i$ and $M_{i}$ is the molecular weight for component i.

\subsection{Degradation Analysis}

Three PBG glass rods of each composition, $9 \mathrm{~mm}$ diameter and $10 \mathrm{~mm}$ length, were put into $30 \mathrm{ml}$ glass vials, immersed in phosphate buffer saline (PBS) and then placed into an incubator at $37{ }^{\circ} \mathrm{C}$. The surface area of each disc was calculated from dimensional measurements taken using a micrometer (Mitutoyo, Japan) and their mass was measured to 4 decimal places using a digital balance (Sartorius, UK).

The period of degradation analysis was 60 days and the time points were days $1,2,3,4,7,9,12,16$, $20,23,26,30,33,37,40,44,47,50,54,58$ and 60 . At each time point, the glass rods were taken out of the vials, excess moisture was removed by blotting the samples dry with tissue and they were then dried in an oven at $50{ }^{\circ} \mathrm{C}$ for 10 minutes. Dimension and mass measurements were taken and the $\mathrm{pH}$ of the solution was measured by using a microprocess $\mathrm{pH}$ meter (Hanna, UK) before returning the samples to the vials with fresh PBS solution. The rate of mass loss was calculated using the following equation:

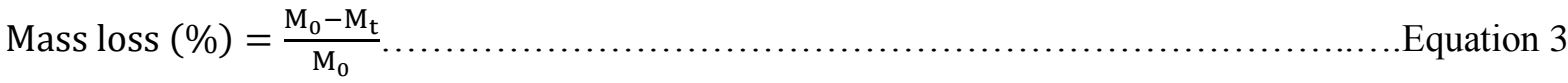

Where $\mathrm{M}_{0}$ is the initial mass $(\mathrm{g})$ and $\mathrm{M}_{\mathrm{t}}$ is the mass at time $\mathrm{t}$. The values of mass loss per unit area, determined via equation 4 , were plotted against time. The slope of the graph was determined by fitting a straight line through the data and passing through the origin point gave the dissolution rate in terms of $\mathrm{kg} \mathrm{m}-2 \mathrm{~s}-1$

Mass loss per unit area $\left(\mathrm{kg} \mathrm{m}^{-2} \mathrm{~s}^{-1}\right)=\frac{\mathrm{M}_{0}-\mathrm{M}_{\mathrm{t}}}{\mathrm{A}_{\mathrm{o}}}$ Equation 4

Where $A_{o}$ is surface area of glass disc at time t.

\subsection{Cell culture}


MG63 cells (human osteosarcoma), obtained from the European Collection of Cell cultures (ECACC), were cultured in Complete Dulbecco's Modified Eagle Medium (CDMEM) consisting of DMEM supplemented with $8.6 \%$ foetal bovine serum (FBS), 1.7\% HEPES buffer, $1.7 \%$ antibioticsantimycotics, $0.86 \%$ glutamine, $0.86 \%$ nonessential amino acids (Gibco Invitrogen, UK) and $0.13 \mathrm{~g} / \mathrm{L}$ ascorbic acid (Sigma Aldrich, UK). Cells were cultured in $75 \mathrm{~cm} 3$ flasks (Falcon, Becton, Dickins and company; UK) at $37{ }^{\circ} \mathrm{C}$ in a humidified atmosphere with $5 \% \mathrm{CO}$. Once confluent, the cells were detached from the flask using trypsin-EDTA solution (HBSS containing $2.5 \mathrm{~g} \mathrm{~L}-1$ trypsin and $0.18 \mathrm{~g}$ L-1 EDTA) and centrifuged at $1200 \mathrm{rpm}$ for 4 minutes to produce a cell pellet which was then resuspended in fresh media. Cell concentration was measured using a haemocytometer and viable cells were identified using trypan blue exclusion via microscopy. The period of cytocompatibility analysis was 14 days, investigated over four time points (i.e. day 1, 3, 7 and 14). All glass discs were immersed in ethanol (99\% Fisher Chemicals, UK) and washed via ultrasonic cleaner, then left under UV light for 1 hour in order to sterilise them prior to cell culture. Tissue culture plastic (TCP) was used as a positive control for cell growth. Cells were seeded onto the disc surfaces at a density of 40,000 cells cm $\mathrm{cm}^{-2}$ and incubated at $37 \mathrm{oC}$ in a humidified atmosphere with $5 \% \mathrm{CO}_{2}$.

\subsection{Alamar Blue Assay}

At designated time points, culture medium was removed from the wells and the samples were washed three times using warm PBS. Warm Alamar Blue solution (1:10 Alamar Blue: Hanks Balanced Salt Solution (HBSS)) was added into each well and incubated for 80 minutes. $100 \mu 1$ aliquots from each well were transferred to a 96-well plate in triplicate and fluorescence was determined via an FLx800 plate reader (BioTekInsruments) at $530 \mathrm{~nm}$ excitation and $590 \mathrm{~nm}$ emission.

\subsection{Alkaline Phosphatase (ALP) Activity}

Alkaline phosphatase activity was determined using an alkaline phosphatase assay from Randox (UK). At the required time points, cell media was removed and the samples were washed three times using warm PBS, then $1 \mathrm{ml}$ sterile distilled water was added into each well. Cells were lysed using a freeze- 
thaw technique three times. A $50 \mu 1$ aliquot of cell lysate was added to a 96-well plate and mixed with $50 \mu \mathrm{l}$ of the alkaline phosphatase substrate (p-nitrophenyl phosphate in diethanolamine buffer at $\mathrm{pH}$ 9.8). Well plates were shaken gently for 5 minutes and the absorbance was measured at wavelengths of $405 \mathrm{~nm}$ excitation and $620 \mathrm{~nm}$ emission using an ELx800 plate reader (BioTek Instruments Inc).

\subsection{DNA Quantification}

The samples were washed and cells were lysed using a freeze-thaw technique as highlighted for the method of alkaline phosphate activity. DNA standards were prepared using calf thymus DNA (sigma, $\mathrm{UK}$ ) and TNE buffer (10 mM Tris, $2 \mathrm{M} \mathrm{NaCl}$ and $1 \mathrm{mM}$ EDTA in sterile distilled water at $\mathrm{pH}$ 7.4) as a diluent. $100 \mu \mathrm{l}$ of Hoechst stain 33258 was added to each well (1 mg of bis-benzimide 33258 in double distilled water and diluted to 1:50 in TNE buffer) and protected in a light-proof container. $100 \mu 1$ aliquots of cell lysate were transferred to a 96-well plate and mixed with $100 \mu$ l Hoechst stain. Fluorescence was determined using a FLx800 plate reader at $360 \mathrm{~nm}$ excitation and $460 \mathrm{~nm}$ emission. DNA concentrations were derived from a standard curve generated by the software KCjunior.

\subsection{Cell Morphology}

After being washed with warm PBS three times at $37{ }^{\circ} \mathrm{C}$, the samples were fixed by applying a $3 \%$ glutaraldehyde in $0.1 \mathrm{M}$ cacodylate buffer for 30 minutes. Fixed samples were then washed twice using $0.2 \mathrm{M}$ cacodylate buffer and covered by $1 \%$ osmium tetroxide in PBS for 45 minutes. Samples were dehydrated gradually using mixtures of ethanol and water from $20 \%$ to $100 \%$ ethanol in discrete $10 \%$ increments, with each step lasting 5 minutes. The final step was finished by covering sample surface with hexamethyldisilazane (HMDS) for 10 mins. All samples were sputter-coated with platinum (Polaron SC7640, UK) and observed via a scanning electron microscope (Philips XL30, UK) operated at $10 \mathrm{kV}$. 


\subsection{Statistical Analysis}

The average values and standard deviation of all data involved in this cytocompatibility study were calculated and analysed using the Prism software (version 6.0, GraphpPad Software, San Diego, CA, USA). A one-way analysis of variance (ANOVA) was calculated with the Tukey multiple post-test to compare the significance of change in one factor with time. The error bars on all the data represent standard error of mean. 


\section{RESULTS}

\subsection{Powder X-ray Diffraction Analysis}

XRD analysis was conducted to investigate the amorphous nature of the formulations produced. According to the XRD trace shown in Figure 1, there was a single broad peak for values of $2 \theta$ between $20^{\circ}$ and $40^{\circ}$ for each composition, with small sharp crystalline peaks on $30^{\circ}$. This indicated that a small crystalline phase was formed in the glass but the most of glasses produced were amorphous. However, the intensity of peak on $30^{\circ}$ was too low to characterise crystal.

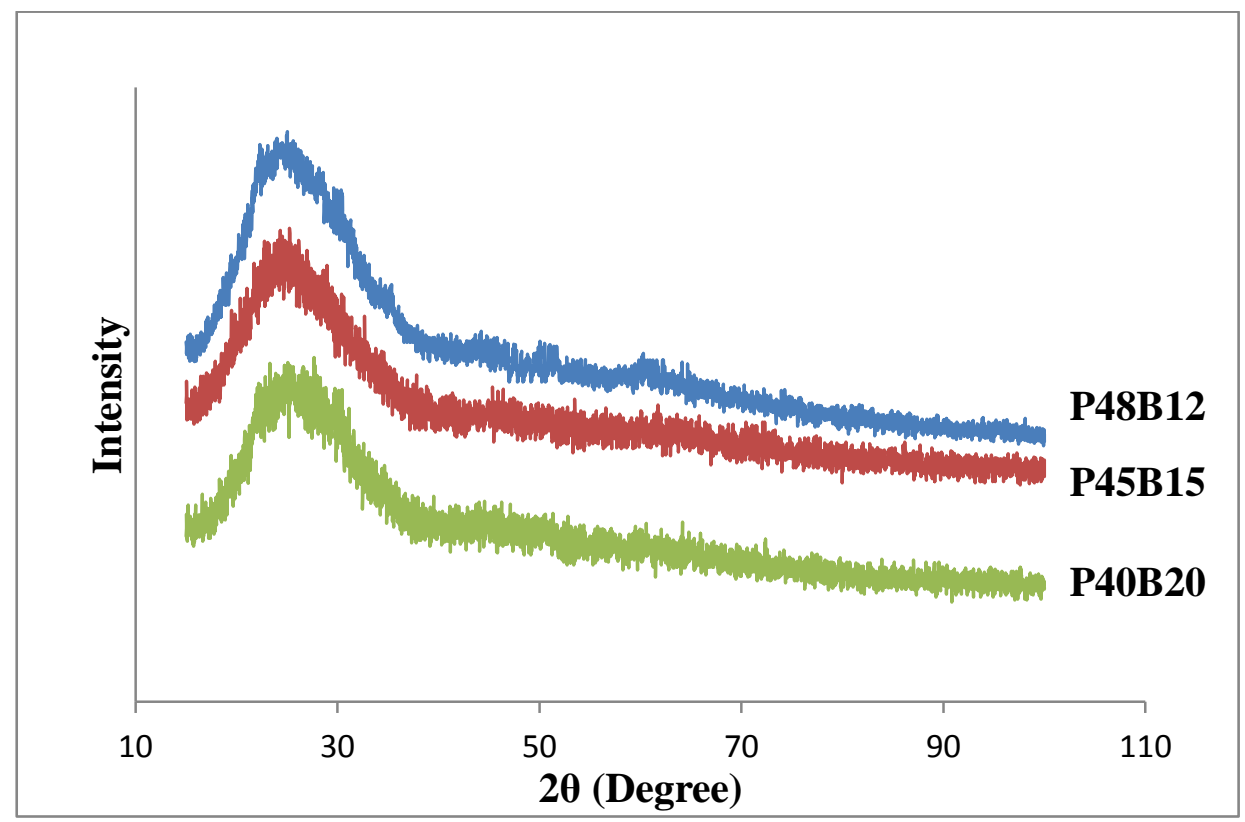

Figure 1: Powder X-ray diffraction pattern for the three glasses. 


\subsection{Fourier Transform Infrared Spectroscopy}

Fourier transform infrared (FTIR) spectroscopy was utilised for characterising structure groups in the glasses. Spectra for the three glasses are shown in Figure 2. Peaks were positioned at approximately $770,850,920,1040$ and $1230 \mathrm{~cm}^{-1}$ for glass P48B12, whilst glass P45B15 had four dominant peaks at 760, 920, 1050 and $1240 \mathrm{~cm}^{-1}$. For glass P40B20, there were three weak peaks around 760, 1240 and $1430 \mathrm{~cm}^{-1}$ and three major peaks at 840,940 and $1040 \mathrm{~cm}^{-1}$. In addition, a weak peak formed at around $680 \mathrm{~cm}^{-1}$. It was evident that the peaks in the spectra were broad. This can be explained by the fact that they consist of overlapping peaks due to multiple vibration modes from both phosphate and borate structural units linked to four metallic elements in the glass system. Peak assignments are summarised in Table 2.

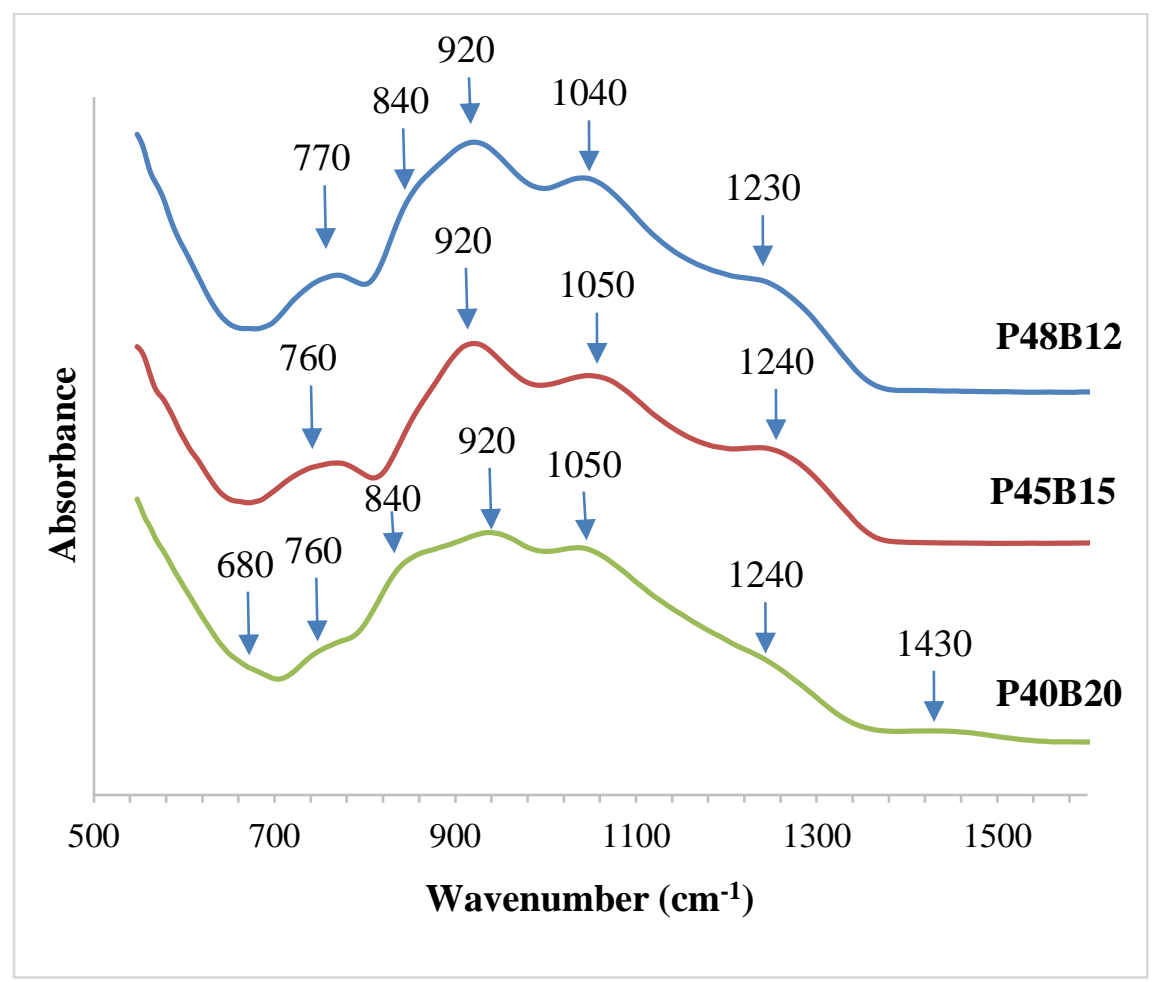

Figure 2: FTIR spectra of the three glasses. 
Table 2: Peak assignments for the Infrared analysis.

\begin{tabular}{|c|c|c|}
\hline wavenumber $\left(\mathrm{cm}^{-1}\right)$ & IR Assignments & Ref \\
\hline $680-720$ & $\mathrm{~B}-\mathrm{O}-\mathrm{B}$ bending vibration in symmetric $\mathrm{BO}_{3}$ triangle units & [42-44] \\
\hline 750-780 & Symmetric stretching mode of P-O-P linkage in the $\mathrm{Q}^{2}$ units & {$[19,45]$} \\
\hline \multirow{2}{*}{ 840-880 } & Stretch vibration of $\mathrm{P}-\mathrm{O}-\mathrm{B}$ linkage in $\mathrm{BO}_{4}$ units & {$[33,46]$} \\
\hline & Symmetric mode of P-O-P in linear $\mathrm{Q}^{2}$ units (metaphosphate) & {$[19,47]$} \\
\hline 900 & Asymmetric stretching vibration of P-O-P linkages in $\mathrm{Q}^{2}$ units & {$[40,48]$} \\
\hline $930-950$ & Stretch vibration of $\mathrm{B}-\mathrm{O}$ in $\mathrm{BO}_{4}$ units (diborate $\mathrm{B}_{4} \mathrm{O}_{7}^{2-}$ group) & {$[40,49]$} \\
\hline $1020-1050$ & $\begin{array}{l}\text { Stretch vibration of } \mathrm{B}-\mathrm{O} \text { in } \mathrm{BO}_{4} \text { units (triborate, tetraborate, } \\
\text { pentaborate) }\end{array}$ & {$[33,50]$} \\
\hline $1237-1280$ & $\begin{array}{l}\text { Modes of boron-oxygen triangular } \mathrm{BO}_{3} \text { units (Pyro and ortho } \\
\text { borate groups) }\end{array}$ & {$[51,52]$} \\
\hline \multirow[t]{2}{*}{$1230-1290$} & $\begin{array}{l}\text { Asymmetric stretching mode of the two non-bridging oxygen atoms } \\
\text { bonded to phosphorus atoms in the } \mathrm{Q}^{2} \text { tetrahedral sites }\end{array}$ & {$[53,54]$} \\
\hline & $\mathrm{P}=\mathrm{O}$ asymmetric stretching vibration & {$[55,56]$} \\
\hline 1400-1500 & Stretch vibration of bonding $\mathrm{B}-\mathrm{O}$ in $\mathrm{BO}_{3}$ units & {$[57,58]$} \\
\hline
\end{tabular}

\subsection{DSC Analysis}

Thermal analysis profiles for the glasses are presented in Figure 3. The corresponding glass transition temperature $\left(\mathrm{T}_{\mathrm{g}}\right)$, onset of crystallisation temperature $\left(\mathrm{T}_{\mathrm{onc}}\right)$, crystallisation temperature $\left(\mathrm{T}_{\mathrm{c}}\right)$, melting temperature $\left(T_{m}\right)$ and liquidus temperature $\left(T_{L}\right)$ have been labelled in Figure 3. The thermal profiles exhibited two melting points ( $\mathrm{T}_{\mathrm{m} 1}$ and $\mathrm{T}_{\mathrm{m} 2}$ ) for $\mathrm{P} 48 \mathrm{~N} 12$ and P40N20 glasses and three melting points $\left(\mathrm{T}_{\mathrm{m} 1}, \mathrm{~T}_{\mathrm{m} 2}\right.$ and $\left.\mathrm{T}_{\mathrm{m} 3}\right)$ for the P45B15 glass. The results are summarised in Table 3. A minor increase in $\mathrm{T}_{\mathrm{g}}$ was observed with increasing $\mathrm{B}_{2} \mathrm{O}_{3}$ content from 12 to $20 \mathrm{~mol} \%$, whilst a decline was revealed in the other temperature points investigated, namely $T_{o n c}, T_{c}$ and $T_{L}$. The values of the processing window $T_{p w}$ 
$\left(\mathrm{T}_{\mathrm{onc}}-\mathrm{T}_{\mathrm{g}}\right.$ ), which indicates the thermal stability for glasses, were seen to decrease from $215^{\circ} \mathrm{C}$ to $164{ }^{\circ} \mathrm{C}$, with increasing content of $\mathrm{B}_{2} \mathrm{O}_{3}$ from 12 to $20 \mathrm{~mol} \%$.

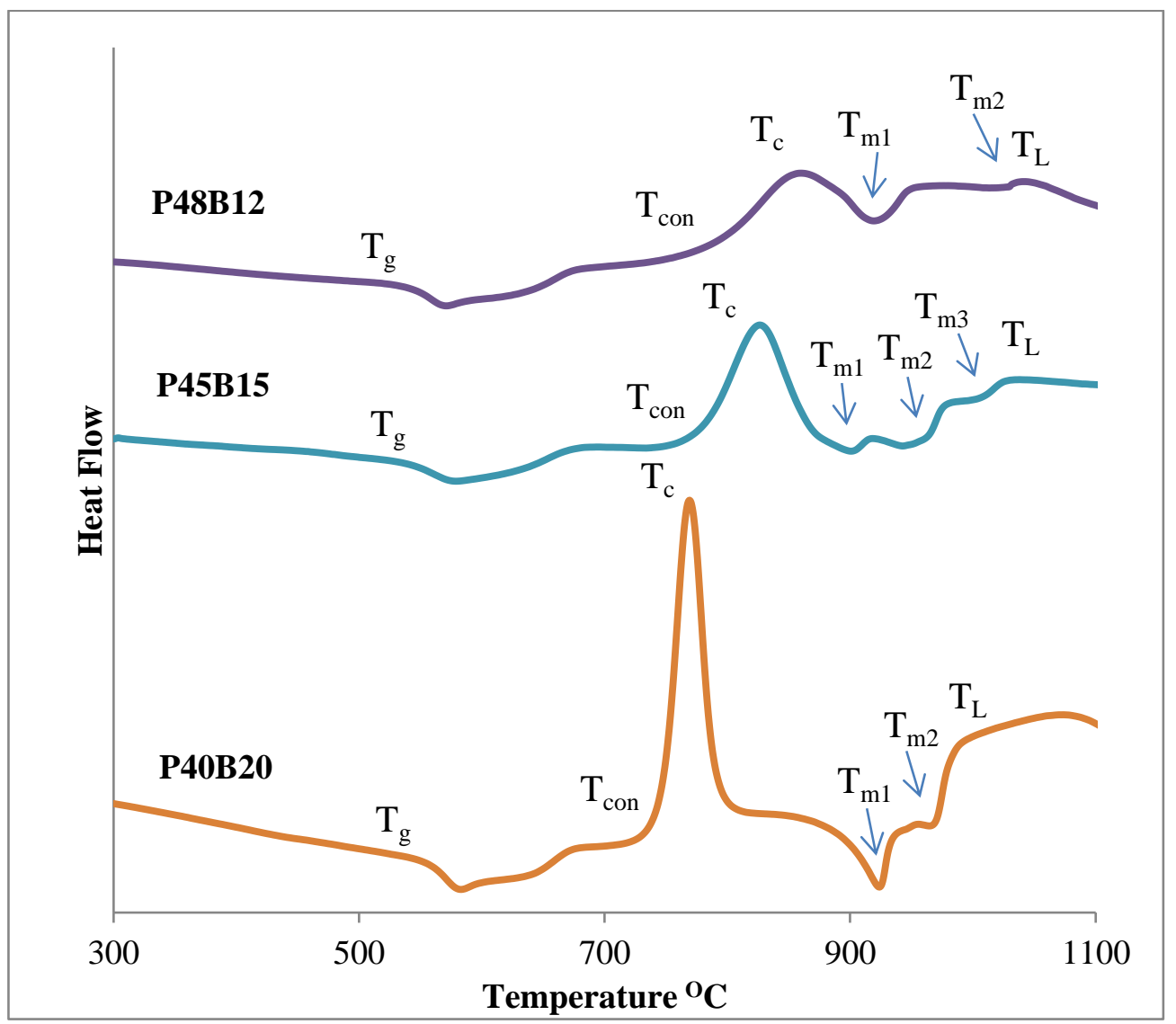

Figure 3: The thermal traces from differential thermal analysis for the three glass formulations that were investigated.

Table 3: Thermal analysis for glass systems investigated as a function of $\mathrm{B}_{2} \mathrm{O}_{3}$ content (mol\%).

\begin{tabular}{|c|c|c|c|c|c|c|}
\hline Glass Code & $\mathbf{T}_{\mathrm{g}}\left({ }^{\circ} \mathbf{C}\right)$ & $\mathbf{T}_{\text {onc }}\left({ }^{\circ} \mathbf{C}\right)$ & $\mathbf{T}_{\mathbf{p w}}\left({ }^{\circ} \mathbf{C}\right)$ & $\mathbf{T}_{\mathrm{c}}\left({ }^{\circ} \mathbf{C}\right)$ & $\mathbf{T}_{\mathrm{m}}\left({ }^{\circ} \mathbf{C}\right)$ & $\mathbf{T}_{\mathbf{L}}\left({ }^{\circ} \mathbf{C}\right)$ \\
\hline \multirow{2}{*}{ P48B12 } & \multirow{2}{*}{$542 \pm 3$} & \multirow{2}{*}{$757 \pm 3$} & \multirow{2}{*}{$215 \pm 6$} & \multirow{2}{*}{$857 \pm 1$} & $919 \pm 2$ & \multirow{2}{*}{$1043 \pm 4$} \\
\hline & & & & & $1012 \pm 9$ & \\
\hline \multirow{3}{*}{ P45B15 } & \multirow{3}{*}{$550 \pm 3$} & \multirow{3}{*}{$750 \pm 4$} & \multirow{3}{*}{$200 \pm 7$} & \multirow{3}{*}{$806 \pm 2$} & $898 \pm 4$ & \multirow{3}{*}{$1015 \pm 2$} \\
\hline & & & & & $953 \pm 4$ & \\
\hline & & & & & $995 \pm 3$ & \\
\hline \multirow{2}{*}{ P40B20 } & \multirow{2}{*}{$566 \pm 4$} & \multirow{2}{*}{$729 \pm 2$} & \multirow{2}{*}{$163 \pm 6$} & \multirow{2}{*}{$768 \pm 1$} & $923 \pm 1$ & \multirow{2}{*}{$987 \pm 2$} \\
\hline & & & & & $966 \pm 2$ & \\
\hline
\end{tabular}




\subsection{Density and Molar Volume Determination}

The values of density $(\rho)$ and molar volume $\left(V_{m}\right)$ were determined and are displayed in Figure 4 . The value of density increased from $2.65 \pm 0.01$ to $2.70 \pm 0.01 \times 10^{3} \mathrm{Kg} \mathrm{m}^{-3}$ with the increase of $\mathrm{B}_{2} \mathrm{O}_{3}$ content. Consequently, the values of the molar volume decreased from $38.3 \pm 0.1$ to $35.2 \pm 0.1 \times 10^{-6}$ $\mathrm{m}^{3} \mathrm{~mol}^{-1}$.

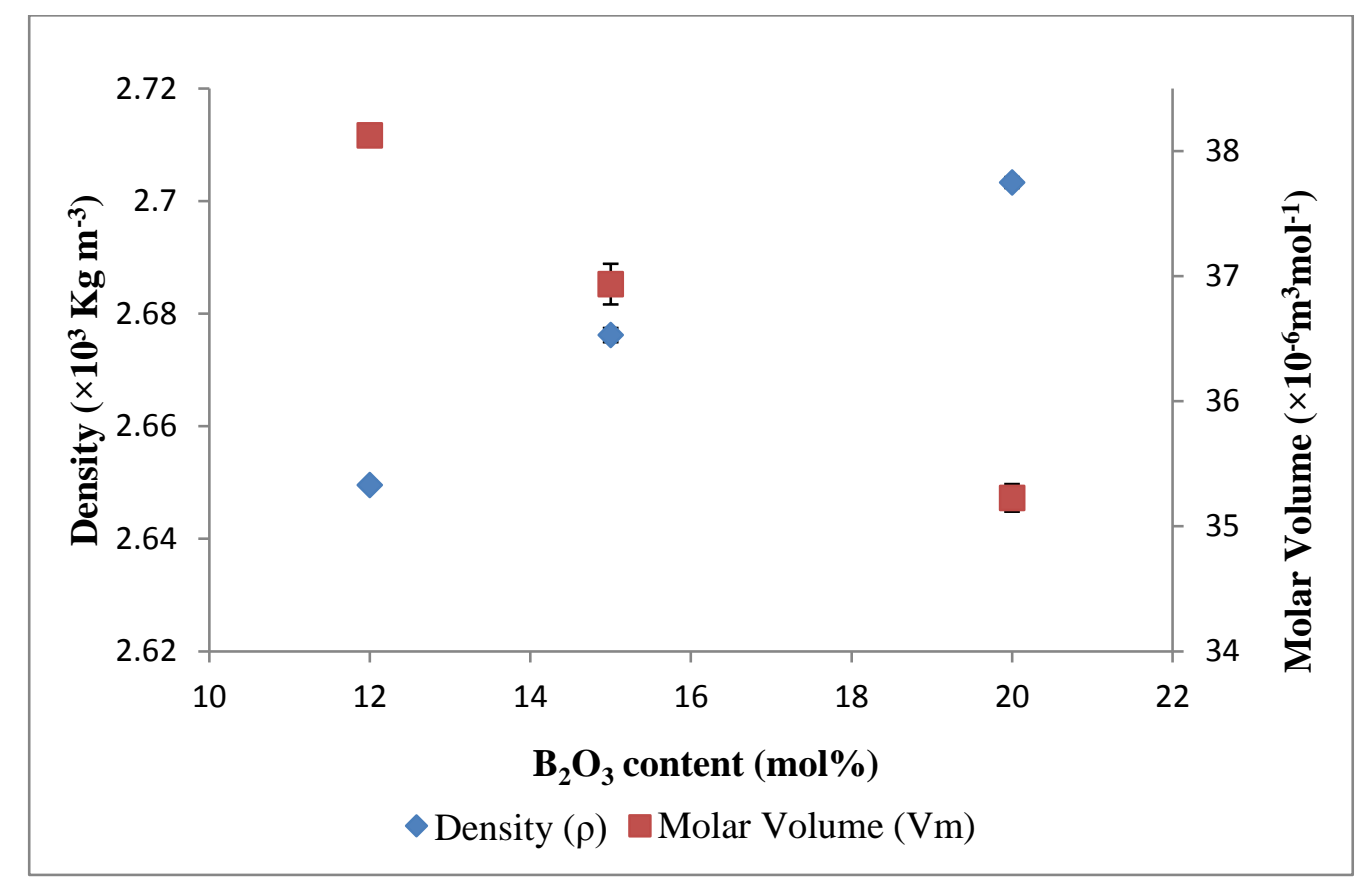

Figure 4: Variation of density $(\rho)$ and molar volume $(\mathrm{Vm})$ of borophosphate glasses as a function of

$$
\mathrm{B}_{2} \mathrm{O}_{3} \text { content (mol\%). }
$$

\subsection{Degradation analysis}

The mass loss (\%) of the borophosphate bulk glasses as a function of degradation time (day) when immersed in PBS at $37{ }^{\circ} \mathrm{C}$ is presented in Figure 5. With increasing $\mathrm{B}_{2} \mathrm{O}_{3}$ content, the mass loss also increased. The total mass loss observed over the full duration of the 60-day study was seen to increase from 1.1 to $1.9 \%$. Furthermore, the dissolution rates (normalised to surface area) are shown in Figure 6. With addition of $\mathrm{B}_{2} \mathrm{O}_{3}$ at the expense of $\mathrm{P}_{2} \mathrm{O}_{5}$, the dissolution rate increased from $9.8 \times 10^{-9} \mathrm{~kg} \mathrm{~m}^{-2} \mathrm{~s}^{-}$ ${ }^{1}$ for $\mathrm{P} 48 \mathrm{~B} 12$ glass with $12 \mathrm{~mol} \% \mathrm{~B}_{2} \mathrm{O}_{3}$ content to $1.7 \times 10^{-8} \mathrm{~kg} \mathrm{~m}^{-2} \mathrm{~s}^{-1}$ for P40B20 glass with $20 \mathrm{~mol} \%$ $\mathrm{B}_{2} \mathrm{O}_{3}$. 


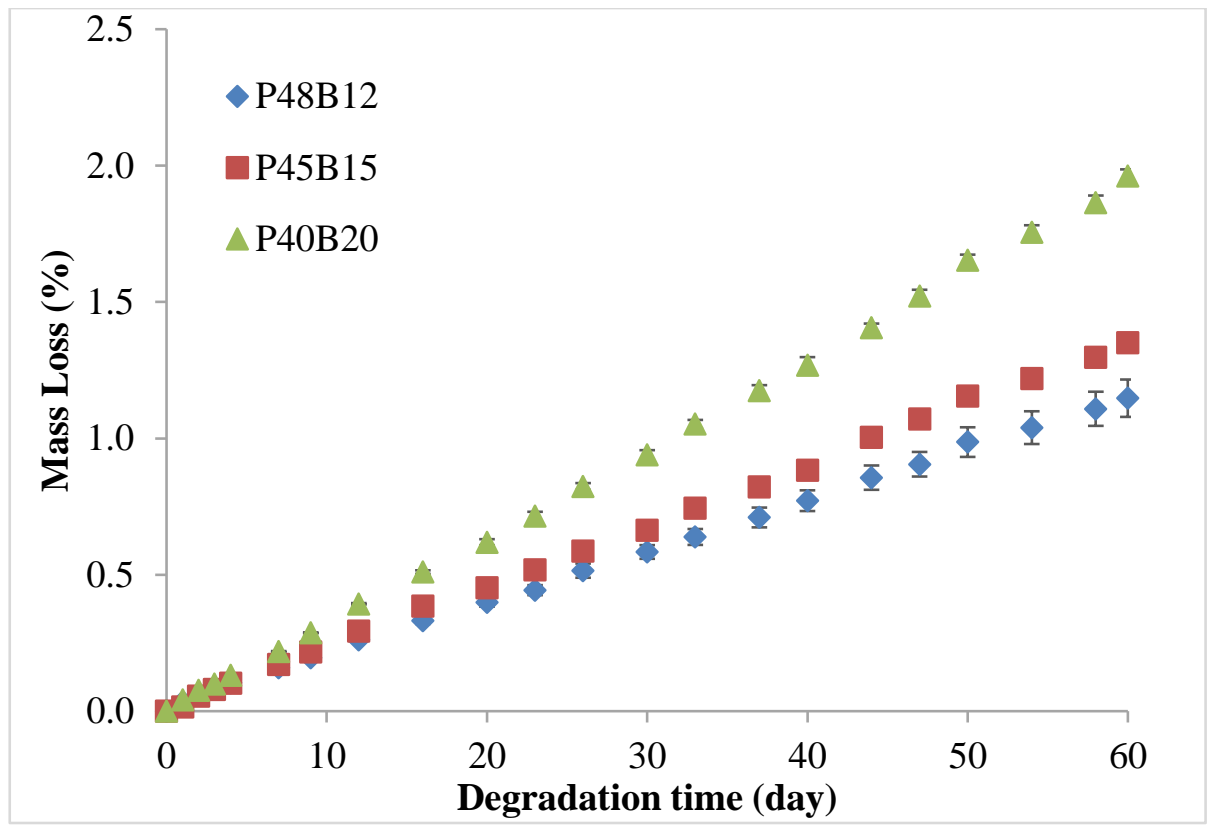

Figure 5: Plot of mass loss of the borophosphateglasss as a function degradation time.

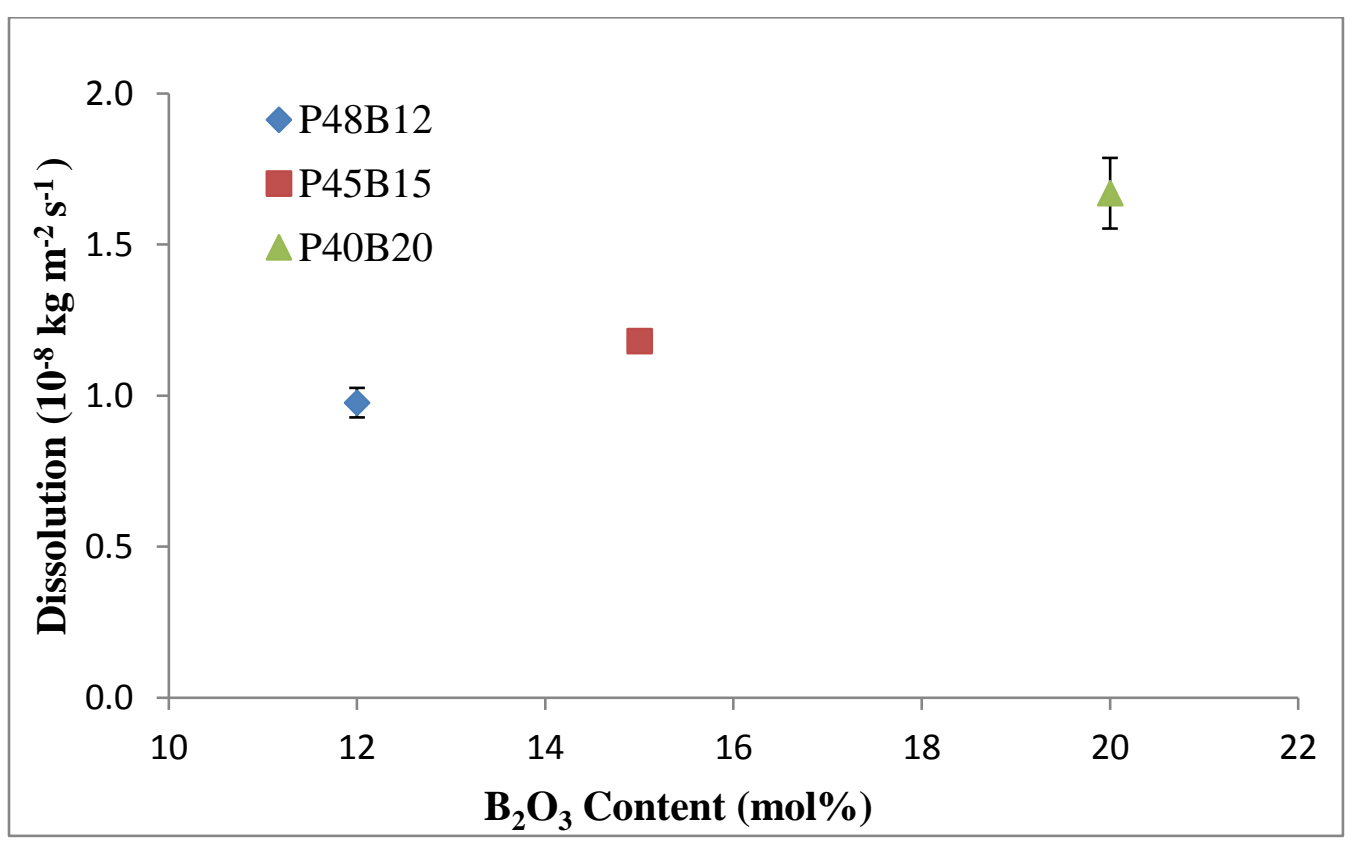

Figure 6: Graph of dissolution rate as a function of $\mathrm{B}_{2} \mathrm{O}_{3}$ content (mol\%). 


\subsection{Cell Metabolic Activity}

The Alamar Blue assay was used to determine the effect of $\mathrm{B}_{2} \mathrm{O}_{3}$ addition on the metabolic activity of osteosarcoma cells (MG63) that were seeded onto the glass surfaces. The cells were cultured on the glass discs for 14 days and the time points were day 1, 3, 7 and 14 (presented in Figure 7). Overall, metabolic activity was seen to increase throughout the 14-day analysis period. The tissue culture plastic (TCP) control group demonstrated slightly higher metabolic activity when compared to the P48B12 glass $(P>0.05)$, and significantly higher when compared to the other two glasses at day 1 and day 3 $(P<0.01)$. Notably, cell metabolic activity on the P48B12 glass was seen to be statistically significant $(P<0.001)$ when compared to the other glasses and the TCP control at days 7 and 14 . By day $14, \mathrm{P} 48 \mathrm{~B} 12$ and P45B15 glass showed significantly higher metabolic activity than the TCP control.

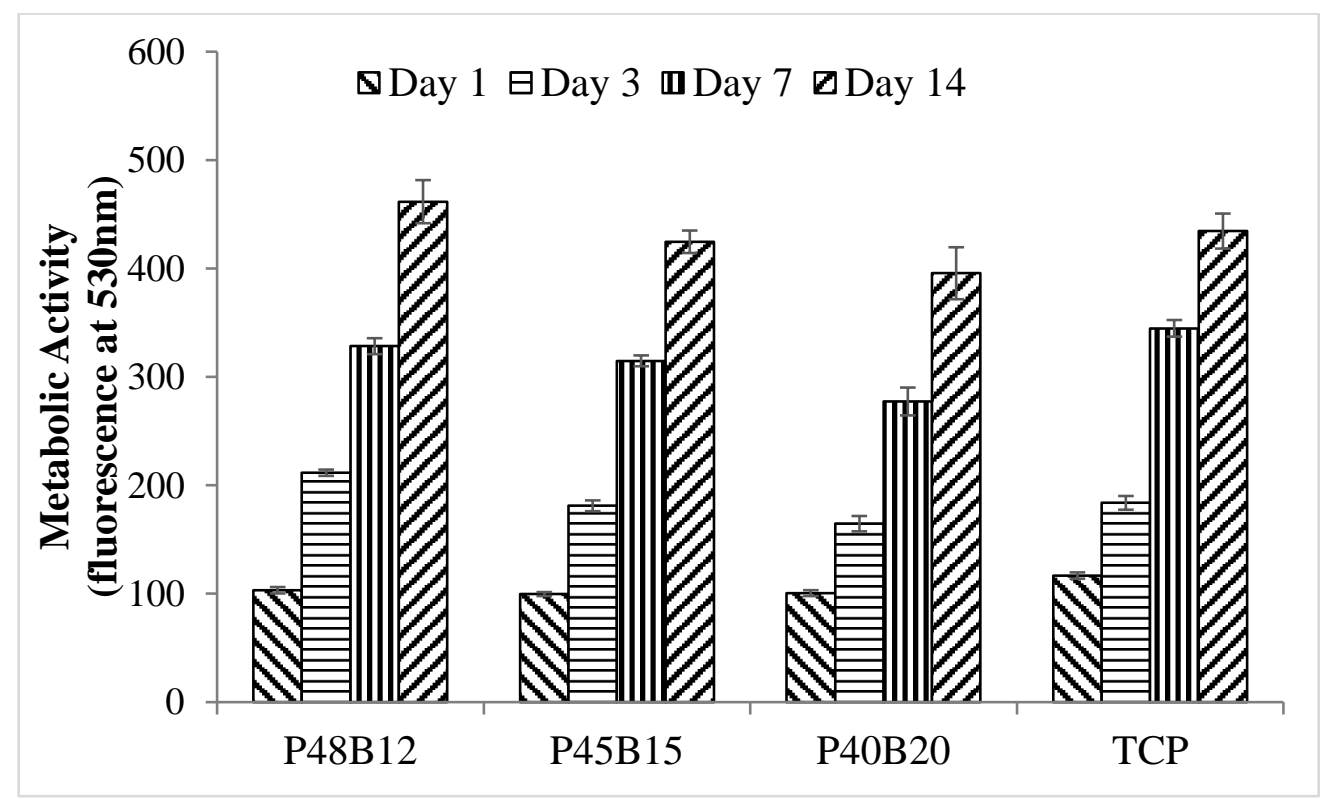

Figure 7: Metabolic activity of MG63 cells culturing on PBGs, as measured by the Alamar Blue assay. The time points are day 1, 03, 7 and 14. Error bars represent the standard error where $n=5$.

\subsection{DNA quantification}

The effect of boron addition on the proliferation of human osteosarcoma cells was determined by measuring the DNA content of the cells cultured for up to 14 days. The Hoechst 33258 DNA assay was 
used to quantify the amount of DNA. The DNA was measured at four time points: days 1, 3, 7 and 14 (See Figure 8). For all the samples, a significant increase in DNA concentration was observed from day 1 to day 14 . During early time period (day 1 and 3$)$, no significant difference $(\mathrm{P}>0.05)$ was observed among the P48B12, P45B15 and P40B20 glasses. P48B12 glass demonstrated statistically significantly higher $(\mathrm{P}<0.001)$ DNA concentration when compared to the P45B15 and P40B20 glasses at day 7 and 14.

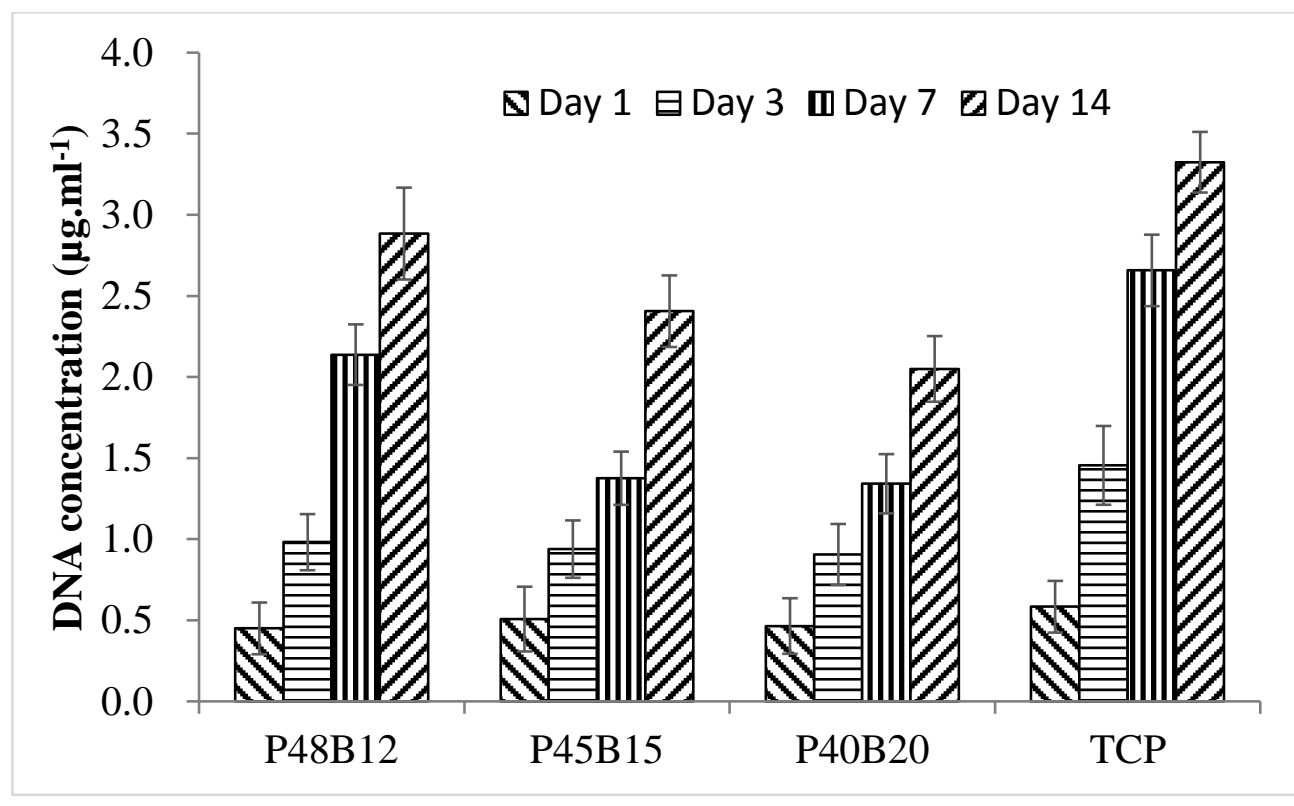

Figure 8: Proliferation of MG63 cells cultured on PBGs, as measured via the Hoechst 33258 DNA assay. The time points are day 1, 3, 7 and 14. Error bars represent the standard error where $n=5$.

\subsection{Alkaline phosphatase activity assay}

The alkaline phosphatase (ALP) assay was used to determine the effect of $\mathrm{B}_{2} \mathrm{O}_{3}$ addition on the alkaline phosphatase activity of osteosarcoma cells (MG63) seeded onto the glass surfaces. The ALP activity was normalised to the DNA concentration of each individual sample. No activity could be detected during the first 3 days. However, ALP activity was observed for all the samples after 7 days of culture (presented in Figure 9). Glass P48B12 and TCP control demonstrated significantly higher ALP activity $(P<0.01)$ than the other sample groups at day 7 . By the last time point (14 days), the P48B12 glass showed a significantly higher $(P<0.01)$ ALP activity when compared to the other glasses and the TCP 
control. In addition, no significant difference $(P>0.05)$ was observed between the activities of P45B15 and P40B20 for either time point.

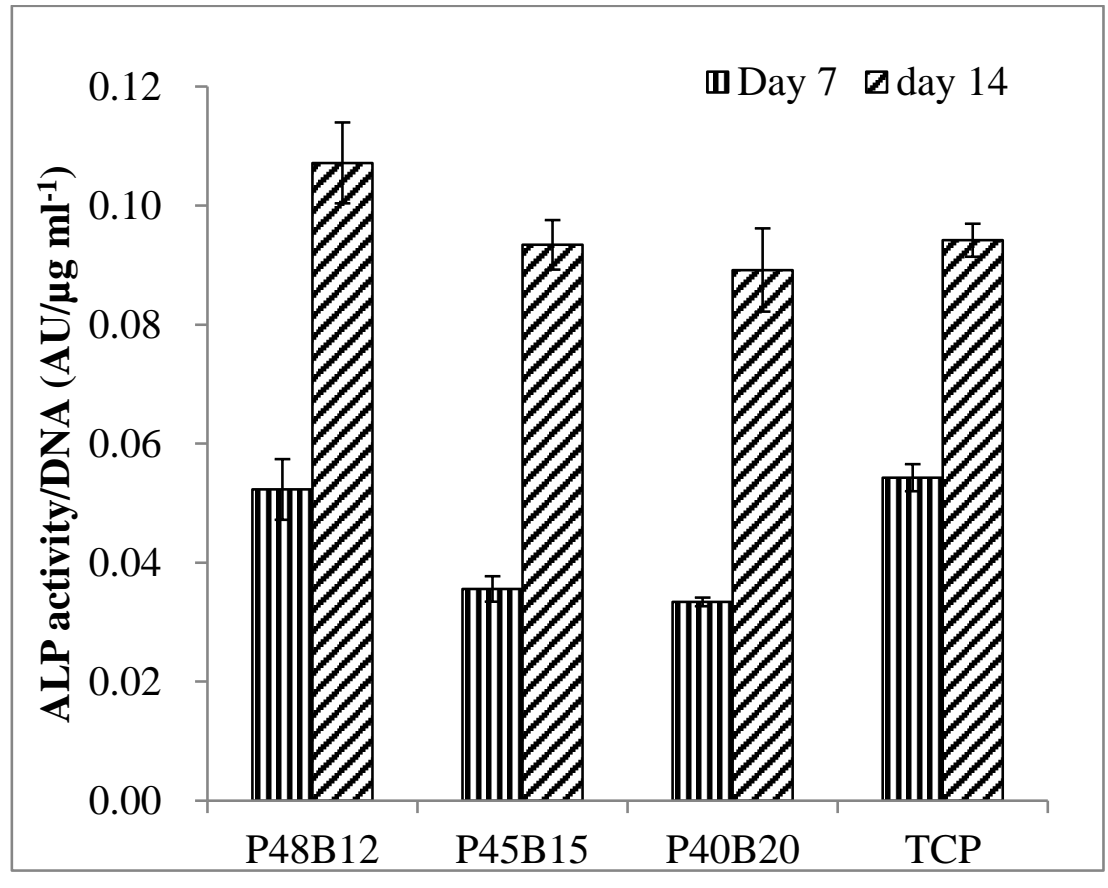

Figure 9: Alkaline phosphatase (ALP) activity of MG63 cells cultured on the surfaces of PBGs. The raw data was normalized by using DNA values obtained for each individual sample. Error bars represent the standard error where $\mathrm{n}=5$.

\subsection{Cell morphology}

The morphology of the cells cultured on the phosphate glass discs was visualised using SEM (Figure 10). In general, the SEM images showed a confluent layer of cells on all glass samples after 7 days of culture. At the early time points ( 1 and 3 days), the P48B12 glass samples (containing 12 mol\% B2O3) had a greater cell density and number of attachment sites (lamellipdia and filopodia), when compared to the glass samples containing 15 and $20 \mathrm{~mol} \%$ Boron oxide (P45B15 and P40B20). After 3 days, there were some larger clusters of MG63 cells with lamellipodia extended to neighbouring cells, leading to the formation of a confluent cell layer at later time points. 


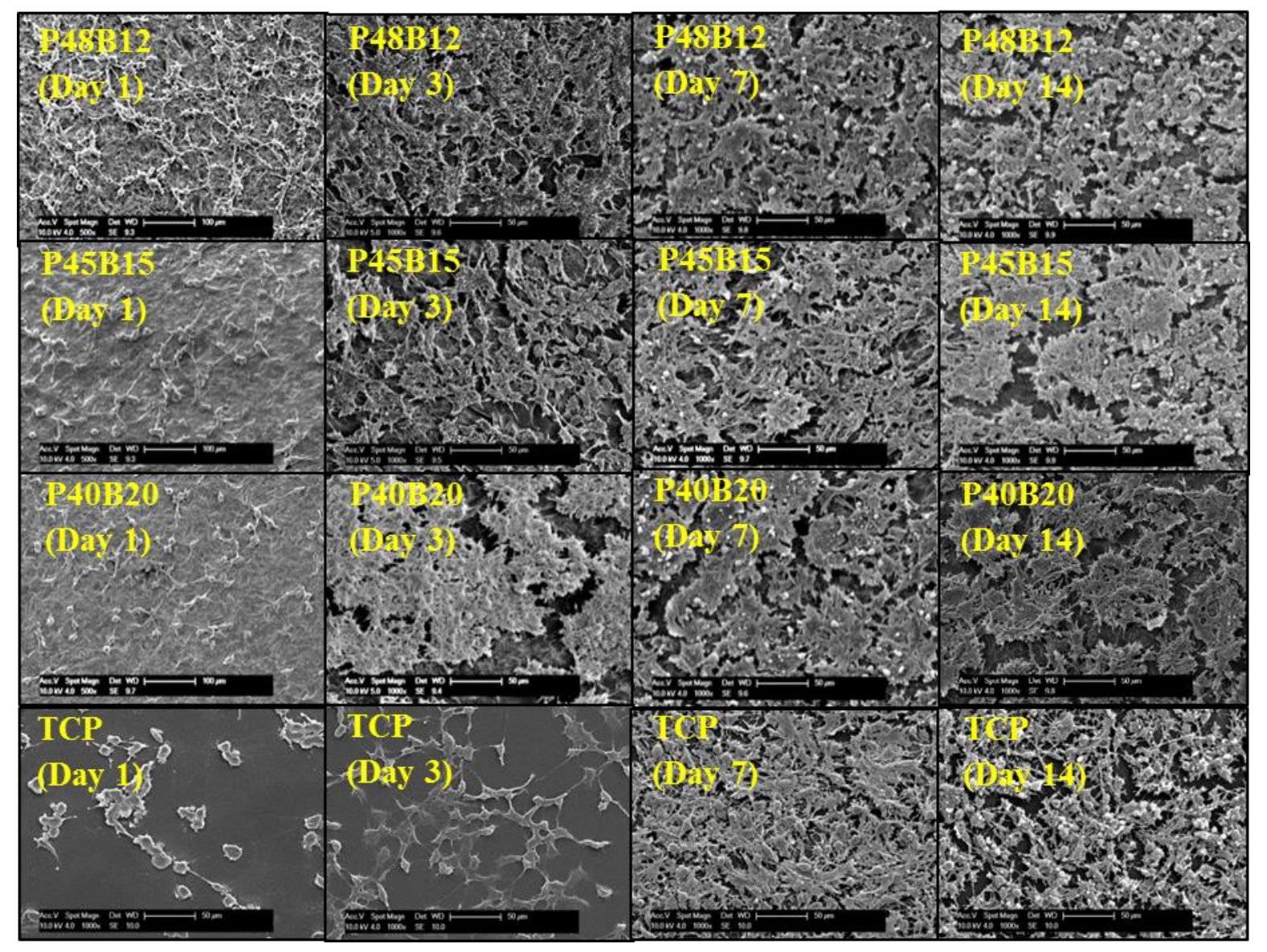

Figure 10: Scanning Electron Microscopy micrographs of MG63 cells cultured on the surface of glass samples P48B12, P45B15, P40N20 and tissue culture plastic (TCP) at four time points: days 1, 3, 7 and 14 . 


\section{DISCUSSION}

The purpose of this study was to investigate manufacture of phosphate-based glass formulations suitable for scale-up multifilament fibre production.

As seen from the XRD pattern in Error! Reference source not found., all the glass samples investigated in this study presented small crystalline peak, it could be attributed to crystallization in small region of amorphous glass. However, it was difficult to be characterised as the intensity of peak was too low to be identified. It is well known that the thermal, degradation and physical properties are dependent on structure and composition $[19,59,60]$. However, it was difficult to obtain quantitative measurements of the distribution of structural groups from the FTIR spectra due to overlapping peaks and stretching modes associated with the presence of different structural groups.

It was also observed from the spectra in Figure 2 that as the content of $\mathrm{B}_{2} \mathrm{O}_{3}$ increased from 12 to 15 mol\%, the peak at $770 \mathrm{~cm}^{-1}$ shifted toward lower wavenumber $760 \mathrm{~cm}^{-1}$ with lower intensity, and the intensity of the peak at $850 \mathrm{~cm}^{-1}$ also diminished. These peak variations were suggested to be due to the decrease in $\mathrm{P}_{2} \mathrm{O}_{5}$ content leading to a depolymerisation of $\mathrm{Q}^{2}$ metaphosphate groups and thus a decrease in symmetric linkages of $\mathrm{P}-\mathrm{O}-\mathrm{P}$ in $\mathrm{Q}^{2}[19,45,47]$. In addition, $\mathrm{B}-\mathrm{O}$ stretch vibration in $\mathrm{BO}_{4}$ units was assigned to a band at $1040 \mathrm{~cm}^{-1}$ where the shift to a higher wavenumber of $1050 \mathrm{~cm}^{-1}$ was suggested to be due to the increase of $\mathrm{B}_{2} \mathrm{O}_{3}$ leading to more $\mathrm{BO}_{4}$ tetrahedral units and the formation of borate groups, such as triborate and tetraborate $[33,50]$. A minor peak shift in this band was also indicative of the content of $\mathrm{BO}_{3}$ units which increased due to the addition of $\mathrm{B}_{2} \mathrm{O}_{3}$ [51-53]. Consequently, there were two different structural units i.e. $\mathrm{BO}_{3}$ and $\mathrm{BO}_{4}$ introduced in the borophosphate glasses in this study, and the $\mathrm{BO}_{3}$ units were seen to increase as well as the $\mathrm{BO}_{4}$ units.

From the FTIR spectra of the P40B20 glass with 20 mol\% $\mathrm{B}_{2} \mathrm{O}_{3}$ content, there were two bands that were not observed in the IR spectra of the other glass formulations. According to the IR assignments in Table 2: Peak assignments for the Infrared analysis., the new presented bands for this glass at $680 \mathrm{~cm}^{-1}$ and $1430 \mathrm{~cm}^{-1}$ were assigned to $\mathrm{B}-\mathrm{O}-\mathrm{B}$ bending vibration and $\mathrm{B}-\mathrm{O}$ stretch vibration in the $\mathrm{BO}_{3}$ units, respectively $[49,50]$. Furthermore, the peak shifts at bands 940 and $1040 \mathrm{~cm}^{-1}$ were observed as $\mathrm{B}_{2} \mathrm{O}_{3}$ 
content increased from $15 \%$ to $20 \%$. This indicated that the content of $\mathrm{Q}^{2}$ metaphosphate groups were reduced continuously, and also suggested that more $\mathrm{BO}_{3}$ and $\mathrm{BO}_{4}$ units had formed in the system, such as pyro borate groups $\left(\mathrm{BO}_{3}\right)$ and diborate, triborate and pentaborate groups $\left(\mathrm{BO}_{4}\right)$ [49-52]. In other words, a broad peak at band $840 \mathrm{~cm}^{-1}$ with $\mathrm{B}_{2} \mathrm{O}_{3}$ reaching $20 \mathrm{~mol} \%$, suggested that the borate units $\left(\mathrm{BO}_{4}\right)$ linked with $\mathrm{PO}_{4}$ units by sharing the negative charge supplied by the oxygen of the modifier to form $\mathrm{BPO}_{4}$ units $[33,46,61]$. As such, $\mathrm{BO}_{4}$ units were incorporated into the phosphate glass chain-like structure as a network former and polymerised the glass network leading to enhancement of the network from a one-dimensional to three-dimensional structure $[62,63]$.

On the whole, with substitution of $\mathrm{B}_{2} \mathrm{O}_{3}$ for $\mathrm{P}_{2} \mathrm{O}_{5}$, the $\mathrm{B} / \mathrm{P}$ ratio increased from 0.25 to 0.5 . The $\mathrm{Q}^{2}$ metaphosphate groups were reduced thus the network of phosphate was depolymerised. However, owing to the increase of tetrahedral $\mathrm{BO}_{4}$ units, B-O-P linkages were formed, developing a new, mixed glass network. As the content of $\mathrm{BO}_{3}$ increased as well as $\mathrm{BO}_{4}$, many borate groups such as diborate and triborate were observed through FTIR spectroscopy. Variation of the structural units observed in this study were also confirmed by Zielniok et al. [64] who determined the content of $\mathrm{BO}_{3}, \mathrm{BO}_{4}$ and $\mathrm{PO}_{4}$ units with various $\mathrm{B} / \mathrm{P}$ ratios by using NMR and summarised that a decrease in $\mathrm{Q}^{2}$ metaphosphate structure was observed along with increases in P-O-B and B-O-B linkages as the $\mathrm{B} / \mathrm{P}$ ratio increased from 0.1 to 0.4 .

According to the DSC results, the $T_{g}$ values increased slightly with the replacement of $\mathrm{P}_{2} \mathrm{O}_{5}$ with $\mathrm{B}_{2} \mathrm{O}_{3}$. An increase of $26{ }^{\circ} \mathrm{C}$ was observed with the content of $\mathrm{B}_{2} \mathrm{O}_{3}$ increasing from 12 to $20 \mathrm{~mol} \%$. This increase was also observed by Raguente et al [49], who found that the higher the boron content in the glass, the higher the $\mathrm{T}_{\mathrm{g}}$ was and therefore the more the network was polymerised. Christense and Lee et al. explained [30,63] that the increased connectivity of short range order structures in the glass system was caused by the creation of $\mathrm{BO}_{4}$ units, which have a higher number of bridging oxygens (BOs) than $\mathrm{PO}_{4}$ units, and due to the formation of $\mathrm{B}-\mathrm{O}-\mathrm{P}$ bonds. However, the increase in $\mathrm{T}_{\mathrm{g}}$ for the glasses in this study was not that remarkable. This could have been due to the reduction of $\mathrm{P}_{2} \mathrm{O}_{5}$ and consequent reduction in $\mathrm{Q}^{2}$ units (including long chain and ring structures). Ahmed et al [65] stated that the 
decreasing trend in $\mathrm{T}_{\mathrm{g}}$ values with decreasing $\mathrm{P}_{2} \mathrm{O}_{5}$ content from 50 to $45 \mathrm{~mol} \%$ was due to network depolymerisation and the occurrence of shorter $\mathrm{Q}^{1}$ units in the glass structure. As such, the increase in $\mathrm{T}_{\mathrm{g}}$ values caused by addition of $\mathrm{B}_{2} \mathrm{O}_{3}$ could be countered by the reduction in $\mathrm{P}_{2} \mathrm{O}_{5}$.

The occurrence of two $T_{m}$ peaks for glass codes P48B12 and P40B20, whilst three $T_{m}$ peaks for glass code P45B15 were indicative of the possible existence of two or three crystalline phases respectively. Even though only one $T_{c}$ and one $T_{\text {onc }}$ peak were observed in each case, it was suggested that the $T_{c}$ peaks and $\mathrm{T}_{\mathrm{onc}}$ peaks could overlap several crystallisation peaks corresponding to the different crystallisation phases.

Crystallisation temperature was seen to decrease with increasing $\mathrm{B}_{2} \mathrm{O}_{3}$ content and the processing window $\mathrm{T}_{\mathrm{pw}}$ was also seen to reduce as well (Table 3). According to Hruby's method [41], the greater the temperature difference between $\mathrm{T}_{\text {onc }}$ and $\mathrm{T}_{\mathrm{g}}$, the more stable the glass is and the easier it is to avoid partial crystallisation during its working operation, such as fibre drawing [66]. Thus, the thermal stability of the glasses in this study was reduced with substitution of $\mathrm{B}_{2} \mathrm{O}_{3}$ for $\mathrm{P}_{2} \mathrm{O}_{5}$. Even though $\mathrm{BO}_{4}$ probably dominated the glass network and improved network stability, an increase in the content of $\mathrm{BO}_{3}$, which does not contribute to connectivity, could have enhanced the crystallisation tendency and reduce the liquidus temperature $\mathrm{T}_{\mathrm{L}}$ of the glass [26]. Even with this reduced thermal stability, the lowest processing window for the glass $\mathrm{P} 40 \mathrm{~B} 20\left(164^{\circ} \mathrm{C}\right)$ was still higher than that of the borophosphate glasses with good fibre drawing performance developed by Sharmin et al [32]. It would suggest that the borophosphate glasses in this study should be considered as good candidates for fibre drawing, which could be confirmed via viscosity analysis and fibre fabrication trials.

The density of the glasses was seen to increase with the substitution of $\mathrm{B}_{2} \mathrm{O}_{3}$ for $\mathrm{P}_{2} \mathrm{O}_{5}$, whereas the molar volume decreased (Figure 4). Christensen et al [31] investigated the density of borophosphate glasses and reported similar results when the content of $\mathrm{B}_{2} \mathrm{O}_{3}$ was increased from 0 to 26 mol\%. This was attributed to the fact that the covalent radius of $\mathrm{B}(853 \mathrm{pm})$ was much lower than that of $\mathrm{P}(1128 \mathrm{pm})$ $[67,68]$. Therefore, the increase in density of the glasses could be explained by a higher packing density of atoms inside the glass structure, which also manifested in a diminution in the molar volume of the 
glasses. The observed decrease in molar volume was also affected by a lower total number of atoms per mole as $\mathrm{P}_{2} \mathrm{O}_{5}$, with seven atoms per unit, were replaced by $\mathrm{B}_{2} \mathrm{O}_{3}$ with five atoms units [69].

During the degradation studies, an increase of $71 \%$ was observed in the dissolution rate and mass loss with increasing $\mathrm{B}_{2} \mathrm{O}_{3}$ content from 12 to $20 \mathrm{~mol} \%$ (see Figure 5 and 6). Though it was evident that increasing $\mathrm{B}_{2} \mathrm{O}_{3}$ could lead to replacement of P-O-P bonds with P-O-B bonds thus forming $\mathrm{BPO}_{4}$ groups and increasing cross-linking thus also improving chemical durability [32, 69-71], Gao et al. [57] found that the chemical durability of borophosphate glass decreased by $50 \%$ when $10 \mathrm{~mol} \% \mathrm{~B}_{2} \mathrm{O}_{3}$ was added. This was also supported by Donald et al [66] who demonstrated that the addition of $\mathrm{B}_{2} \mathrm{O}_{3}$ could both improve and retard the chemical durability of phosphate based glasses depending on the glass composition. In this study, the FTIR results indicated that both $\mathrm{BO}_{4}$ and $\mathrm{BO}_{3}$ units were present in the glass system as the content of $\mathrm{B}_{2} \mathrm{O}_{3}$ increased. Whilst the $\mathrm{BO}_{4}$ units may join in the phosphate glass structure to improve chemical durability as mentioned before $[32,59,70,72]$, the $\mathrm{BO}_{3}$ units with low cross-linking density could not fully form a three-dimensional structure thus disrupting the glass network and decreasing chemical durability $[57,73]$.

The results in the present study demonstrated that incorporation of $12-20 \mathrm{~mol} \% \mathrm{~B}_{2} \mathrm{O}_{3}$ into the glass system showed little detrimental effect on cell metabolic activity and cell proliferation (see Figure 7 and 8). Cell density on the surfaces of the samples increased from day 1 to day 7 and the morphology of the cells presented good confluent layers (Figure 10). The metabolic activity decreased as the content of $\mathrm{B}_{2} \mathrm{O}_{3}$ increased from 12 to $20 \mathrm{~mol} \%$, whereas it was significantly higher $(\mathrm{P}<0.001)$ for the $\mathrm{P} 48 \mathrm{~B} 12$ glass formulation at later points (day 7 and day 14) when compared to the TCP control group. Additionally, after 7 days the P48B12 group demonstrated statistically significant higher $(\mathrm{P}<0.001)$ DNA concentration when compared to P45B15 and P40B20 groups.

Fu et al [36] suggested that boron concentrations below $0.65 \mathrm{mM}$ were able to support the proliferation of stem cells. It can be seen from Figure 6 that glasses with a higher $\mathrm{B}_{2} \mathrm{O}_{3}$ content had higher dissolution rates, thus it was reasonable to suppose that more borate ions were released which could have had a detectable effect on the cell metabolic activity. Although the exact concentrations of borate ions $\left(\mathrm{BO}_{3}\right)^{3-}$ 
leached into media were not determined, it would seem that the concentration of borate ions leached from P48B12 bulk glass was below the threshold of negative effect on biocompatibility whilst those of P45B15 and P40B20 bulk glasses were equal to or higher than the threshold. In order to confirm exact threshold value, it would be beneficial to include boron ion release analysis in future cytocompatibility studies.

A proposed function of the alkaline phosphatase (ALP) that is generated by osteoblasts is in matrix mineralisation during osteoblast growth and bone formation [74]. ALP assays exhibited a similar profile to the Alamar Blue assays, with ALP activity for the $\mathrm{P} 48 \mathrm{~B} 12$ samples being significantly higher $(\mathrm{P}<0.01)$ than the other glass samples and TCP at the last time point (see Figure 9Error! Reference source not found.). These results indicated that MG63 cells were able to carry out an osteogenic function on the bulk glasses investigated in this study [36]. Potential factors affecting the ALP activity included the interaction of borate ions in the media with the alkaline phosphatase and inhibition of activity due to alteration of the glycoprotein in ALP via chelation of the carbohydrate residues on the protein surface [75]. It was also hypothesized that lower ALP activity was due to the higher concentration of ions leached from the glass leading an increase of cytotoxicity and a reduction in $\mathrm{pH}$ [76]. Thus, the enhancement of ALP activity for P48B12 glass could be associated with its better chemical durability which contributed to lower concentration of ions and maintain $\mathrm{pH}$ value of the media [32].

The results in this study showed that addition of boron into phosphate based glasses has a significant effect on the glass properties via introducing $\mathrm{BO}_{3}$ and $\mathrm{BO}_{4}$ units. These can act to both disrupt the phosphate chain structure whilst $\mathrm{BO}_{4}$ units are able to create a new borophosphate chain structure. A large addition of boron can cause a negative effect on the thermal stability, whereas the processing window was still larger than that of the borophosphate glasses developed by Sharmin et al. [32] who showed that her glasses had good fibre forming ability. However, viscosity analysis and fibre trials will be considered in future research in order to confirm the fibre forming properties of the glasses investigated in this study. In the cytocompatibility studies, the presence of boron in the glass appears to have a positive effects on cells at $12 \mathrm{~mol} \%$ inclusion, but with detrimental effects above this level. This 
may be as a result of the higher degradation rate of the glasses with higher boron content. In summary, formulation P48B12 was found to have the best thermal properties and biocompatibility, making it the most promising candidate to develop scale-up fibre production for use in fibre reinforced bioresorbable composites.

\section{CONCLUSIONS}

With the substitution of $\mathrm{B}_{2} \mathrm{O}_{3}$ for $\mathrm{P}_{2} \mathrm{O}_{5}$ in the glass system studied, both $\mathrm{BO}_{4}$ and $\mathrm{BO}_{3}$ structural units were introduced to the glass, as confirmed by FTIR analysis. An increase in $\mathrm{BO}_{4}$ units polymerised the phosphate glass network by forming B-O-P linkages; hence the glass network was strengthened. The strengthening effect on the glass network was evident from a slight increase in $\mathrm{T}_{\mathrm{g}}$, density. Conversely, the presence of $\mathrm{BO}_{3}$ units in the glass disrupts the glass network, reducing its resistance to crystallisation and making the glass structure more susceptible to hydrolysis. As a consequence, thermal stability and chemical durability were reduced.

For cytocompatibility, addition of boron into the glass systems at $12 \mathrm{~mol} \%$ presented positive effects on the cell metabolic activity, proliferation, differentiation and morphology. Addition of boron at more than $12 \mathrm{~mol} \%$ caused a derogatory effect.

Overall, the P48B12 glass formulation demonstrated the best thermal, chemical and biological properties for consideration as a candidate for use in fibre drawing trials and composite manufacture. 


\section{REFERENCES}

[1] I-H Lee, S-H Shin, F Foroutan, NJ Lakhkar, M-S Gong, JC Knowles (2013) Journal of NonCrystalline Solids 363: 57. Doi:10.1016/j.jnoncrysol.2012.11.036

[2] M Kellomaki, H Niiranen, K Puumanen, N Ashammakhi, T Waris, P Tirmala (2000) Biomaterials 21: 2495.

[3] MS Mohammadi, I Ahmed, N Muja, CD Rudd, MN Bureau, SN Nazhat (2011) Journal of materials science. Materials in medicine 22: 2659. Doi:10.1007/s10856-011-4453-x

[4] P Haque, A Parsons, I Ahmed, DJ Irvine, GS Walker, CD Rudd (2010) International Committee on Composite Materials.

[5] G Jiang, ME Evans, IA Jones, CD Rudd, CA Scotchford, GS Walker (2005) Biomaterials 26: 2281. Doi:10.1016/j.biomaterials.2004.07.042

[6] LL Hench, J Wilson (1984) Science 226: 630.

[7] LL Hench, RJ Splinter, WC Allen, TK Greenlee (1971) Journal of biomedical materials research 5: 117. Doi:10.1002/jbm.820050611

[8] JR Jones (2013) Acta biomaterialia 9: 4457. Doi:10.1016/j.actbio.2012.08.023

[9] A Moya, PNd Aza, P Pena, Sd Aza Pendas (2007) Boletin de la Sociedad Española de Cerámica y Vidrio 46: 45.

[10] EA Abou Neel, DM Pickup, SP Valappil, RJ Newport, JC Knowles (2009) Journal of Materials Chemistry 19: 690. Doi:10.1039/b810675d

[11] RK Brow (2000) Journal of Non-Crystalline Solids 263\&264: 1.

[12] YK Lee, RZ LeGeros (2008) Key Engineering Materials 377: 43.

[13] I Ahmed, D Ready, M Wilson, JC Knowles (2006) Journal of biomedical materials research. Part A 79: 618. Doi:10.1002/jbm.a.30808

[14] E Abou Neel, I Ahmed, J Pratten, SN Nazhat, JC Knowles (2005) Biomaterials 26: 2247. Doi:10.1016/j.biomaterials.2004.07.024

[15] EA Abou Neel, I Ahmed, JJ Blaker, et al. (2005) Acta biomaterialia 1: 553. Doi:10.1016/j.actbio.2005.05.001

[16] EA Abou Neel, I Ahmed, JC Knowles (2007) Key Engineering Materials 330-332: 161.

[17] AJ Parsons, I Ahmed, P Haque, et al. (2009) Journal of Bionic Engineering 6: 318. Doi:10.1016/s1672-6529(08)60132-8

[18] P Haque, AJ Parsons, IA Barker, et al. (2010) Composites Science and Technology 70: 1854. Doi:10.1016/j.compscitech.2010.06.012

[19] P Haque, I Ahmed, A Parsons, R Felfel, G Walker, C Rudd (2013) Journal of Non-Crystalline Solids 375: 99. Doi:10.1016/j.jnoncrysol.2013.05.008

[20] G Walter, J Vogel, U Hoppe, P Hartmann (2001) journal of Non-Crystalline Solids 296: 212.

[21] I Ahmed, AJ Parsons, G Palmer, JC Knowles, GS Walker, CD Rudd (2008) Acta biomaterialia 4: 1307. Doi:10.1016/j.actbio.2008.03.018

[22] EA Abou Neel, JC Knowles (2008) Journal of materials science. Materials in medicine 19: 377. Doi:10.1007/s10856-007-3079-5

[23] AJ Parsons, M Evans, CD Rudd, CA Scotchford (2004) Journal of biomedical materials research. Part A 71: 283. Doi:10.1002/jbm.a.30161

[24] I Ahmed, A Parsons, A Jones, G Walker, C Scotchford, C Rudd (2010) Journal of biomaterials applications 24: 555. Doi:10.1177/0885328209102761

[25] MS Hasan, I Ahmed, AJ Parsons, GS Walker, CA Scotchford (2012) Journal of materials science. Materials in medicine 23: 2531. Doi:10.1007/s10856-012-4708-1 
[26] J Massera, C Claireaux, T Lehtonen, J Tuominen, L Hupa, M Hupa (2011) Journal of NonCrystalline Solids 357: 3623. Doi:10.1016/j.jnoncrysol.2011.06.037

[27] M Karabulut, B Yuce, O Bozdogan, H Ertap, GM Mammadov (2011) Journal of Non-Crystalline Solids 357: 1455. Doi:10.1016/j.jnoncrysol.2010.11.023

[28] G Yuan, T Zhang, A Inoue (2003) Materials Transactions 44: 2271.

[29] S Gaylord, B Tincher, L Petit, K Richardson (2009) Materials Research Bulletin 44: 1031. Doi:10.1016/j.materresbull.2008.11.002

[30] R Christensen, J Byer, G Olson, SW Martin (2012) Journal of Non-Crystalline Solids 358: 826. Doi:10.1016/j.jnoncrysol.2011.12.068

[31] R Christensen, J Byer, G Olson, SW Martin (2012) Journal of Non-Crystalline Solids 358: 583. Doi:10.1016/j.jnoncrysol.2011.10.018

[32] N Sharmin, MS Hasan, AJ Parsons, et al. (2013) BioMed research international 2013: 1. Doi:10.1155/2013/902427

[33] F Wang, Q Liao, G Xiang, S Pan (2014) Journal of Molecular Structure 1060: 176. Doi:10.1016/j.molstruc.2013.12.049

[34] D Larink, H Eckert, M Reichert, SW Martin (2012) The Journal of Physical Chemistry C 116: 26162. Doi:10.1021/jp307085t

[35] JW Lim, ML Schmitt, RK Brow, SW Yung (2010) Journal of Non-Crystalline Solids 356: 1379. Doi:10.1016/j.jnoncrysol.2010.02.019

[36] $\mathrm{H} \mathrm{Fu}, \mathrm{Q} \mathrm{Fu}, \mathrm{N}$ Zhou, et al. (2009) Materials Science and Engineering: C 29: 2275. Doi:10.1016/j.msec.2009.05.013

[37] RF Brown, MN Rahaman, AB Dwilewicz, et al. (2009) Journal of biomedical materials research. Part A 88: 392. Doi:10.1002/jbm.a.31679

[38] MA Ouis, AM Abdelghany, HA ElBatal (2012) Processing and Application of Ceramics 6: 141.

[39] A Hoppe, NS Guldal, AR Boccaccini (2011) Biomaterials 32: 2757. Doi:10.1016/j.biomaterials.2011.01.004

[40] R Ciceo-Lucacel, T Radu, O Ponta, V Simon (2014) Materials Science and Engineering: C 39: 61. Doi:10.1016/j.msec.2014.02.025

[41] A Hrubý (1972) Czech J Phys 22: 1187. Doi:10.1007/BF01690134

[42] H Doweidar, G El-Damrawi, M Al-Zaibani (2013) Vibrational Spectroscopy 68: 91. Doi:10.1016/j.vibspec.2013.05.015

[43] H Doweidar, YM Moustafa, K El-Egili, I Abbas (2005) Vibrational Spectroscopy 37: 91. Doi:10.1016/j.vibspec.2004.07.002

[44] A Saranti, I Koutselas, MA Karakassides (2006) Journal of Non-Crystalline Solids 352: 390. Doi:10.1016/j.jnoncrysol.2006.01.042

[45] PY Shih, TS Chin (1999) Materials Chemistry and Physics 60: 50.

[46] MS Gaafar, SY Marzouk, HA Zayed, LI Soliman, AH Serag El-Deen (2013) Current Applied Physics 13: 152. Doi:10.1016/j.cap.2012.07.007

[47] YM Moustafa, K El-Egili (1998) Journal of Non-Crystalline Solids 240: 144.

[48] A Kiani, JV Hanna, SP King, et al. (2012) Acta biomaterialia 8: 333. Doi:10.1016/j.actbio.2011.08.025

[49] B Raguenet, G Tricot, G Silly, M Ribes, A Pradel (2012) Solid State Ionics 208: 25. Doi:10.1016/j.ssi.2011.11.034

[50] S Rani, S Sanghi, N Ahlawat, A Agarwal (2014) Journal of Alloys and Compounds 597: 110. Doi:10.1016/j.jallcom.2014.01.211

[51] L Balachander, G Ramadevudu, M Shareefuddin, R Sayanna, YC Venudhar (2013) ScienceAsia 39: 278. Doi:10.2306/scienceasia1513-1874.2013.39.278

[52] AM Abdelghany (2012) The Open Spectroscopy Journal: 9.

[53] SP Valappil, D Ready, EAA Neel, et al. (2008) Advanced Functional Materials 18: 732. Doi:10.1002/adfm.200700931 
[54] D Carta, DM Pickup, JC Knowles, I Ahmed, ME Smith, RJ Newport (2007) Journal of NonCrystalline Solids 353: 1759. Doi:http://dx.doi.org/10.1016/i.jnoncrysol.2007.02.008

[55] M Abid, M Et-tabirou, M Taibi (2003) Materials Science and Engineering B 97: 20.

[56] YM Moustafa, K El-Egili, H Doweidar, I Abbas (2004) Physica B: Condensed Matter 353: 82. Doi:10.1016/j.physb.2004.09.004

[57] H Gao, T Tan, D Wang (2004) Journal of controlled release : official journal of the Controlled Release Society 96: 21. Doi:10.1016/j.jconrel.2003.12.030

[58] K Kumari, S Ram, RK Kotnala (2011) Materials Chemistry and Physics 129: 1020. Doi:10.1016/j.matchemphys.2011.05.051

[59] DS Brauer, N Karpukhina, RV Law, RG Hill (2010) Journal of Non-Crystalline Solids.

[60] T Harada, H In, H Takebe, K Morinaga (2004) J. Am. Ceram. Soc. 87: 408.

[61] F Wang, Q Liao, K Chen, S Pan, M Lu (2014) Journal of Alloys and Compounds 611: 278. Doi:10.1016/j.jallcom.2014.05.117

[62] L Koudelka, P Mosner (2000) Materials Letters 42: 194.

[63] ETY Lee, ERM Taylor (2005) Journal of Physics and Chemistry of Solids 66: 47. Doi:http://dx.doi.org/10.1016/i.jpcs.2004.08.030

[64] D Zielniok, C Cramer, H Eckert (2007) Chemistry of Materials 19: 3162. Doi:10.1021/cm0628092

[65] I Ahmed, M Lewis, I Olsen, JC Knowles (2004) Biomaterials 25: 491. Doi:10.1016/s01429612(03)00546-5

[66] IW Donald, BL Metcalfe, SK Fong, LA Gerrard (2006) Journal of Non-Crystalline Solids 352: 2993. Doi:10.1016/j.jnoncrysol.2006.04.007

[67] Z-H Jiang, Q-Y Zhang (2014) Progress in Materials Science 61: 144. Doi:10.1016/j.pmatsci.2013.12.001

[68] C Sunandana (2009) IOP Conference Series: Materials Science and EngineeringIOP Publishing, [69] L Koudelka, P Mosner (2001) Journal of Non-Crystalline Solids 293-295: 635.

[70] YB PENG, DE DAY (1991) Glass technology 32: 166.

[71] K Magyari, R Stefan, A Vulpoi, L Baia (2015) Journal of Non-Crystalline Solids 410: 112. Doi:http://dx.doi.org/10.1016/j.jnoncrysol.2014.11.033

[72] J Massera, Y Shpotyuk, F Sabatier, et al. (2015) Journal of Non-Crystalline Solids 425: 52. Doi:http://dx.doi.org/10.1016/j.jnoncrysol.2015.05.028

[73] J Ning, A Yao, D Wang, et al. (2007) Materials Letters 61: 5223. Doi:10.1016/j.matlet.2007.04.089

[74] P Pietschmann (2012) Principles of osteoimmunology: molecular mechanisms and clinical applications. Springer Vienna,

[75] Y Kaup, M Schmid, A Middleton, U Weser (2003) Journal of Inorganic Biochemistry 94: 214. Doi:10.1016/s0162-0134(03)00002-3

[76] M Uo, M Mizuno, Y Kuboki, A Makishima, F Watari (1998) Biomaterials 19: 2277. Doi:http://dx.doi.org/10.1016/S0142-9612(98)00136-7 
2 